\title{
PENERAPAN INQUIRY LEARNING BERBASIS LINGKUNGAN UNTUK MENINGKATKAN AKTIVITAS DAN HASIL BELAJAR TEMATIK
}

\author{
Sohifatul Hayati \\ Program Studi Pendidikan Profesi Guru_FKIP, Universitas Kristen Satya Wacana \\ J1. Diponegoro 52-60 Salatiga \\ Email: 952017050@student.uksw.edu \\ Nyoto Harjono \\ Program Studi Pendidikan Profesi Guru-FKIP, Universitas Kristen Satya Wacana \\ J1. Diponegoro 52-60 Salatiga \\ Email: nyoto.harjono@staff.uksw.edu
}

\begin{abstract}
This study aims to increase the activities and thematic learning outcomes through the application of an environmentbased Inquiry model. The type of research used is classroom action research in two cycles with the look, think, and act stages. The subjects of the study were grade 4A students of SDN Salatiga 06, totaling 33 students. Data collection techniques used in this study are test and non-test techniques. Nontes technique in the form of observations on student activities, this observation is done by observation, and documentation during the learning process. This research is said to be successful if at least $80 \%$ of students get a score of penelitian 75 . The results of the study show: (1) The score of pre-cycle activity in grade $4 \mathrm{~A}$ is $43.77 \%$ and the score of completeness of the results of pre-cycle learning of students is $64 \%$ with the average score 60.50 ; (2) The score of student activity in the first cycle was $72.02 \%$ and the completeness score of student learning outcomes was $73.50 \%$ with an average score of 72.30; (3) Student activity scores in cycle II amounted to $83.50 \%$ with an average score of 83.15 and student completeness learning outcomes on a $91 \%$ cycle with an average value of 87.25 . These data indicate an increase in student activity and learning outcomes in cycle I and cycle II. Based on the description above, it can be concluded that the application of an environment-based inquiry learning model can increase the activities and thematic learning outcomes.
\end{abstract}

Keywords :

Inquiry model, thematic learning, student activity, student learning outcomes

\begin{abstract}
Abstrak :
Penelitian ini bertujuan untuk meningkatkan aktivitas dan hasil belajar tematik melalui penerapan model pembelajaran Inquiry berbasis lingkungan. Jenis penelitian yang digunakan adalah penelitian tindakan kelas dalam dua siklus dengan tahap look, think, dan act. Subjek penelitian adalah siswa kelas 4A SDN Salatiga 06 yang berjumlah 33 siswa. Teknik pengumpulan data yang digunakan pada penelitian ini yaitu teknik tes dan nontes. Teknik nontes berupa pengamatan terhadap aktivitas siswa, pengamatan ini dilakukan dengan observasi, dan dokumentasi saat proses pelaksanaan pembelajaran. Penelitian ini dikatakan berhasil apabila sekurang-kurangnya $80 \%$ siswa memperoleh nilai $\geq 75$. Hasil penelitian menunjukkan : (1) Skor aktivitas pra siklus di kelas 4A sebesar $43,77 \%$ dan skor ketuntasan hasil belajar belajar siswa pra siklus sebesar 64\% dengan nilai rata-rata 60,50; (2) Skor aktivitas siswa pada siklus I sebesar 72,02\% dan skor ketuntasan hasil belajar siswa sebesar 73,50\% dengan nilai rata-rata 72,30; (3) Skor aktivitas siswa pada siklus II sebesar 83,50\% dengan nilai rata-rata 83,15 dan skor ketuntasan hasil belajar siswa pada siklus $91 \%$ dengan nilai rata-rata 87,25 . Data tersebut menunjukkan adanya peningkatan aktivitas dan hasil belajar siswa pada siklus I dan siklus II . Berdasarkan data tersebut, maka disimpulkan bahwa penerapan model pembelajaran inquiry berbasis lingkungan dapat meningkatkan aktivitas dan hasil belajar tematik.
\end{abstract}

Kata Kunci :

Model Inquiry, Pembelajaran tematik, Aktivitas siswa, Hasil belajar siswa 


\section{A. PENDAHULUAN}

Pembelajaran mempunyai peranan penting dalam pendidikan. Melalui pembelajaran seseorang dapat memperoleh pengetahuan baru yang bermakna bagi dirinya. Menurut Briggs (1992) dalam Rifai dan Ani (2011:191) pembelajaran adalah seperangkat peristiwa yang mempengaruhi siswa sehingga siswa memperoleh kemudahan dalam mempelajari berbagai ilmu pengetahuan baru. Undang-Undang Sistem Pendidikan Nasional Nomor 20 Tahun 2003 Bab 1 Pasal 1 menyebutkan bahwa "pembelajaran adalah proses interaksi siswa dengan pendidik dan sumber belajar pada suatu lingkungan belajar."

Berdasarkan definisi pembelajaran tersebut, tujuan pembelajaran adalah memberikan kemudahan kepada siswa dalam memperoleh ilmu pengetahuan baru pada suatu lingkungan belajar. Pembelajaran yang baik adalah pembelajaran yang memberikan pengalaman yang bermakna bagi siswa. Pembelajaran bermakna akan membuat siswa memahami konsep-konsep melalui pengalaman langsung dan menghubungkan konsep yang belum dipahami dengan konsep sebelumnya yang sudah di pahami.

Pembelajaran yang memberikan pengalaman bermakna bagi siswa adalah pembelajaran yang bersifat tematik. Pembelajaran tematik adalah model pembelajaran terpadu yang menggunakan tema untuk menggaitkan beberapa mata pelajaran. (Kememndikbud, 2013:8). Pembelajaran tematik mengacu pada tema yang sudah ditentukan dalam kurikulum 2013 yang selanjutnya dapat dikembangkan oleh guru untuk disesuaikan dengan karakteristik siswa dan lingkungan setempat. Melalui tema siswa lebih mudah menghubungkan satu konsep dengan konsep yang lain.

Pembelajaran tematik di Indonesia sudah mulai diberlakukan dalam dunia pendidikan sejak kurikulum tingkat satuan pendidikan (KTSP) tahun 2006. Pemerintah melakukan beberapa kali revisi terhadap komponen pembelajaran tematik hingga akhirnya diberlakukan kurikulum 2013. Pada kurikulum 2013 pembelajaran tematik diberlakukan untuk semua jenjang kelas di sekolah dasar dari kelas 1 sampai 6.

Kompetensi yang ingin dicapai sesuai dengan kurikulum 2013 mencakup ranah sikap, pengetahuan, dan keterampilan. Ketiga ranah ini diperlukan bagi siswa untuk mewujudkan dirinya sebagai manusia seutuhnya sebagaimana yang tertuang dalam tujuan pendidikan nasional. Kompetensi spiritual dijabarkan menjadi dua yakni sikap spiritual dan sosial. Dengan demikian secara umum kompetensi yang ingin dicapai terdiri dari 4 ranah yang mencakup sikap spiritual, sikap sosial, pengetahuan, dan keterampilan yang selanjutnya disebut kompetensi Inti (KI). Kompetensi pengetahuan pada jenjang pendidikan dasar yaitu memahami pengetahuan faktual, konseptual, prosedural, dan metakognitif dengan cara mengamati, menanya, dan mencoba sehingga dapat menunjukkan keterampilan berpikir kreatif, produktif, kritis, mandiri, kolaboratif, dan komunikatif. (Permendikbud No 21).

Berdasarkan kompetensi yang ingin dicapai pada kurikulum 2013, maka diharapkan pembelajaran mampu mendorong siswa dapat berpikir kritis, kreatif, produktif, mandiri, kolaboratif, dan komunikatif. Oleh karena itu, proses pembelajaran hendaknya dilakukan dengan memberikan kesempatan kepada siswa untuk menemukan pengetahuannya melalui sesuatu yang mereka lakukan atau alami sendiri. Siswa tidak semata mata memahami pengetahuan yang sudah ada, tetapi siswa melakukan proses untuk menenmukan sendiri pengetahuannya. Selain itu, pembelajaran hendaknya dikaitkan dengan lingkungan sekitar agar bermakna bagi siswa. Pemanfaatan lingkungan sekitar sebagai sumber belajar merupakan suatu upaya untuk meningkatkan pengetahuan dan pemahaman siswa terhadap dunia sekitarnya. 
(Hendrawati, 2013:62) . Berbagai jenis lingkungan, seperti lingkungan sosial budaya, lingkungan alam (fisik) maupun lingkungan biologis merupakan sejumlah faktor yang dapat membuat siswa dihadapkan pada fakta atau konsep dunia nyata yang dapat memicu siswa berpikir lebih kritis. (Nooryono, 2009: 14). Berdasarkan uraian di atas dapat disimpulkan bahwa lingkungan mempunyai peran penting dalam membantu siswa memahami suatu konsep baru. Siswa memahami konsep baru dengan mengaitkan konsep lama yang telah dimilikinya. Konsep lama tersebut dapat digali dari fenomena atau peristiwa yang terjadi di lingkungan sekitar siswa, sehingga siswa akan lebih mudah memahami pengetahuan barunya.

Dengan kata lain, siswa membangun pengetahuan barunya melalui pengetauan lokal yang dimiliknya, sehingga konsepkonsep pengetahuannya akan lebih mudah terkait dan dipahami oleh siswa.

Mengacu pada kurikulum yang berlaku, sebagian besar sekolah di Indonesia sudah menerapkan kurikulum 2013 termasuk sekolah-sekolah di kota Salatiga. Salah satu sekolah yang sudah menerapkan kurikulum 2013 adalah SD Negeri Salatiga 06. Berdasarkan hasil observasi yang telah dilakukan, SD Negeri Salatiga 06 sudah melaksanakan pembelajaran sesuai tuntutan kurikulum 2013. Pelaksanaan pembelajaran di SD Negeri Salatiga 06 sudah sesuai dengan buku guru dan buku siswa yang merupakan buku panduan dari pemerintah. Hal yang sama juga dilakukan oleh guru kelas 4A yang sudah berusaha menciptakan pembelajaran tematik yang disesuaikan dengan buku siswa dan guru. Berdasarkan hasil refleksi yang dilakukan bersama guru kelas 4A, masih terdapat beberapa permasalahan yang muncul antara lain: (1) siswa cenderung memperoleh materi dari aktivitas mendengar dan melihat, (2) siswa memahami materi dengan cara menghafal sehingga mudah lupa, (4) siswa kesulitan dalam menyelesaikan materi berkaitan dengan kehidupan sehari-hari, pembelajaran yang dilaksanakan kurang kontekstual sehingga siswa sulit memahami materi pembelajaran. Hal tersebut berdampak pada hasil penilaian tengah semester (PTS) pada SD Negeri Salatiga 06, hanya 67\% siswa yang memenuhi kriteria ketuntatasan minimal (KKM) pada muatan mapel IPA, sedangkan sebanyak $33 \%$ belum memenuhi KKM. Hal yang sama juga terjadi pada muatan mapel Bahasa Indonesia, sebanyak $39 \%$ siswa belum memenuhi KKM, siswa yang memenuhi KKM pada muatan tersebut hanya $61 \%$

Menindaklanjuti permasalahan tersebut peneliti bersama kolaborator merasa permasalahan tersebut penting dan mendesak untuk segera diselesaikan. Berpijak pada tuntutan kurikulum 2013 dan teori konstruktivisme bahwa siswa hendaknya membangun pengetahuannya sendiri melalui penemuan siswa terkait materi atau konsep baru. Proses menemukan itu penting dalam pembelajaran, karena melalui proses menemukan, konsep baru yang diperoleh siswa akan lebih melekat. Pembelajaran inquiry menenkankan pada proses mencari dan menemukan. Model inquiry memberikan kesempatan kepada siswa untuk menemukan sendiri materi pelajarannya, sehingga merangsang siswa untuk berpikir kritis. (Hosnan, 2014: 341).

Kunandar (2010:371) menyatakan bahwa pembelajaran Inquiry merupakan kegiatan pembelajaran yang mendorong siswa untuk belajar dengan keterlibatan aktif dalam melakukan percobaan yang memungkinkan siswa menemukan prinsip/konsep tertentu.

Model inquiry merupakan model yang menekankan pada proses penyelidikan dalam upaya menjawab pertanyaan/permasalahan. Proses yang dilakukan mencakup pengumpulan informasi, membangun pengetahuan, dan mengembangkan pemahaman yang 
mendalam tentang sesuatu yang diteliti. (Sani, 2014:89)

Freinet dalam Sani (2014: 89) menyatakan bahwa pengetahuan yang diperoleh seseorang tidak cukup hanya dengan mengamati, mendengarkan penjelasan atau sekedar melihat demonstrasi. Perolehan pengetahuan dimulai dengan pengalaman siswa, dimana siswa terlibat langsung dalam proses menemukan pengetahuan barunya.

Beberapa penelitian yang telah dilakukan, menunjukkan bahwa model Inquiry dapat meningkatkan aktivitas dan hasil belajar siswa. Penelitian yang menunjukkan bahwa model inquiry meningkatkan aktivitas dan hasil belajar siswa antara lain dilakukan oleh Ely Sarantika Sukma (2017:117), Aditya Rakhmawan, dkk (2015: 151), Endah Hendarwati (2013: 66 ), Femillia Elsa (2014: 30) yang menunjukkan bahwa pembelajaran Inquiry dapat meningkatkan aktivitas dan hasil belajar siswa.

Berdasarkan beberapa penelitian yang telah dilakukan, belum terdapat penelitian yang menerapkan model pembelajaran Inquiry berbasis lingkungan.

Sedangkan hakikatnya suatu proses pembelajaran yang sesuai dengan pendekatan saintifik adalah pembelajaran yang mendorong siswa untuk membangun pemahaman mereka sendiri dengan menggunakan peristiwa atau kejadian yang terdapat disekitarnya agar membuat mereka berpikir kritis, dan memiliki keterampilan untuk mengembangkan pengetahuan atau konsep yang mereka peroleh. Pengembangan konsep tersebut dapat dilakukan dengan cara mendekatkan siswa belajar mengenai fenomena yang terjadi di kehidupan seharihari dengan memanfaatkan lingkungan sekitar sebagai sumber belajar. Sumber belajar berupa lingkungan dapat meningkatkan aktivitas dan hasil belajar siswa, membuat siswa peka terhadap masalah sosial yang terjadi di masyarakat, serta membuat siswa terampil mengatasi masalah yang terjadi di lingkungan sekitarnya. ( Hendarwati, 2013:61).

Adapun rumusan masalah dalam penelitian ini yaitu: (1) Bagaimanakah penerapan metode Inquiry berbasis lingkungan dapat meningkatkan aktivitas siswa dalam pembelajaran tematik pada siswa kelas 4A SD Negeri Salatiga 06?; (2) Apakah peningkatan aktivitas siswa melalui penerapan metode inquiry dapat meningkatkan hasil belajar tematik pada siswa kelas 4A SD Negeri Salatiga 06?

Berdasarkan rumusan masalah tersebut peneleitian ini bertujuan untuk meningkatkan hasil belajar tematik melalui penerapan metode inquiry berbasis lingkungan.

Penelitian ini juga memberikan manfaat baik secara teoretis maupun secara praktis. Secara teoretis, penelitian ini bermanfaat untuk menambah pengetahuan tentang model pembelajaran inquiry berbasis lingkungan yang dapat meningkatkan hasil belajar tematik, terutama yang dapat membantu siswa dalam membangun pengetahuannya sendiri melalui pengalaman belajar berbasis lingkungan. Secara praktis, manfaat penelitian bagi peneliti adalah menambah wawasan pengetahuan, dan keterampilan peneliti terkait metode Inquiry berbasis lingkungan; bagi guru menambah alternatif metode pembelajaran untuk menciptakan suasana yang menyenangkan, kondusif, dan partisipasif, sehingga mendapatkan hasil belajar yang optimal. Hal tersebut tentunya dapat memaksimalkan peran guru sebagai fasilitator dan evaluator untuk memudahkan siswa untuk membangun sendiri pengetahuannya berdasarkan kondisi lingkungannya.

Berdasarkan uraian latar belakang tersebut, peneliti bersama tim kolaborator melakukan penelitian tindakan kelas dengan judul "Penerapan Model Inquiry Berbasis Lingkungan untuk Meningkatkan Hasil Belajar Tematik pada Siswa Kelas 4A SD 
Negeri Salatiga 06." Peneliti memilih model pembelajaran Inquiry karena dapat meningkatkan aktivitas belajar siswa melalui proses penemuan atau percobaan yang mereka lakukan. Dengan demikian, siswa dapat membangun pemahamannya sendiri sehingga menimbulkan kebermaknaan proses pembelajaran bagi siswa. Kebermaknaan pembelajaran akan membuat siswa tidak mudah melupakan pengetahuan yang telah mereka dapatkan.

\section{Kajian Pustaka \\ Pembelajaran tematik}

Menurut Trianto

(2010:117)

pembelajaran tematik merupakan gabungan antar berbagai bidang kajian seperti IPA, Matematika, Bahasa Indonesia, IPS, dan PPKn dalam satu kesatuan (holistic) dan keterpaduan (integralistic). Pembelajaran dilaksanakan dalam satu kesatuan, tidak lagi terpisah-pisah berdasarkan tema-tema tertentu. Suyanto dan Jihad (2013: 253) mengemukakan bahwa pembelajaran tematik merupakan pembelajaran yang menggunakan tema sebagai pemersatu atau pengikat materi pembelajaran dari beberapa mata pelajaran secara terintegrasi. Suyanto dan Jihad (2014: 252) lebih lanjut mengemukakan bahwa tema merupakan suatu alat atau wahana untuk mengenalkan berbagai konsep dan pengetahuan kepada siswa secara utuh. Dengan adanya tema siswa akan terlatih mengaitkan berbagai informasi yang bisa membekali mereka untuk menghadapi atau terlibat langsung secara aktif dalam kehidupan nyata. Tema dirumuskan dirumuskan dengan tujuan untuk menyatukan isi kurikulum, sehingga berbagai aspek seperti sikap, keterampilan dan pengetahuan akan diperoleh secara komprehensif.

Berdasarkan uraian mengenai pembelajaran tematik, dapat disimpulkan bahwa pembelajaran tematik merupakan suatu pembelajaran yang menggunakan sebagai pengikat konsep antar mata pelajaran secara terintegrasi untuk mengembangkan seluruh potensi yang dimiliki siswa.

Ciri-ciri pembelajaran tematik menurut Suyanto dan Jihad (2013: 254) menyatakan ciri khas pembelajaran tematik antara lain: (1) Berpusat pada siswa (Student Centered); (2) memberikan pengalaman langsung (Direct Experiences);

Pemisahan antar mata pelajaran tidak begitu jelas; (4) menyajikan konsep dari berbagai mata pelajaran dalam suatu proses pembelajaran; (5) bersifat fleksibel (luwes); (6) hasil pembelajaran sesuai dengan minat dan kebutuhan siswa; (7) menggunakan prinsip belajar sambil bermain dan menyenangkan.

Pada pelaksanaan pembelajaran tematik tentunya melibatkan guru, siswa dan sarana yang digunakan selama proses pembelajaran. Adapun prinsip yang harus dipenuhi dalam pembejaran tematik menurut Suyanto dan Jihad (2014: 258) yaitu: (1) bersifat kontekstual atau terintegrasi dengan lingkungan: (2) proses dan kegiatan belajar harus dirancang sedemikian rupa agar siswa dapat bekerja secara sungguh-sungguh dalam menemukan konsep sekaligus mengaplikasikannya; (3) efisiensi dari segi waktu, beban materi, metode, dan penggunaan sumber belajar yang otentik.

\section{Model Pembelajaran Inquiry}

Metode inquiry merupakan metode yang menekankan pada proses penyelidikan dalam upaya menjawab pertanyaan/permasalahan. Proses yang dilakukan mencakup pengumpulan informasi, membangun pengetahuan, dan mengembangkan pemahaman yang mendalam tentang sesuatu yang diteliti. (Sani, 2014:89)

Sintak metode pembelajaran inquiry menurut Shoimin (2014: 85-86) antara lain: (1) Guru membina suasana yang responsive di antara siswa; (2) Guru mengemukakan permasalahan untuk diinquirikan (ditemukan) melalui cerita, film, gambar dan sebagainya. 
Permasalahan tersebut dapat ditampilkan dengan mengajukan pertanyaan, merumuskan, dan memperjelas cerita pada gambar; (3) mengajukan pertanyaan kepada siswa yang bersifat mencari atau mengajukan informasi atas data tentang permasalahan tersebut; (4) merumuskan hipotesis yang merupakan jawaban dari pertanyaan tersebut; (5) Menguji hipotesis; (6) mengambil kesimpulan.

\section{Pembelajaran Berbasis Lingkungan}

Belajar berbasis lingkungan artinya siswa belajar dengan cara mengamati dan melakukan kegiatan secara langsung yang terdapat di lingkungannya baik di rumah atau di sekolah untuk mendapatkan pengetahuan/konsep baru. Mulyasa (2014:134) menyatakan bahwa suatu pembelajaran akan menarik perhatian siswa apabila apa yang dipelajari diangkat dari lingkungannya, sehingga apa yang dipelajari dapat bermanfaat bagi lingkungannya.

UNESCO dalam Mulyasa (2014:135) mengemukakan jenis-jenis lingkungan yang dapat didayagunakan oleh siswa untuk kepentingan pembelajaran. Jenis lingkungan tersebut antara lain: (1) lingkungan yang meliputi faktor-faktor fisik, biologi, sosioekonomi, dan budaya yang berpengaruh baik secara langsung maupun tidak langsung; (2) sumber masyarakat yang meliputi setiap unsur atau fasilitas yang ada dalam suatu kelompok masyarakat; (3) Ahli-ahli setempat yang meliputi tokoh-tokoh masyarakat yang memiliki pengetahuan khusus berkaitan dengan kepentingan pembelajaran.

\section{METODE}

Penelitian ini merupakan penelitian tindakan kelas. Tindakan yang akan diberikan berupa penerapan model pembelajaran inquiry berbasis lingkungan. Berikut desain penelitian tindakan kelas menggunakan model stringer (Yaumi, 2014: 45):

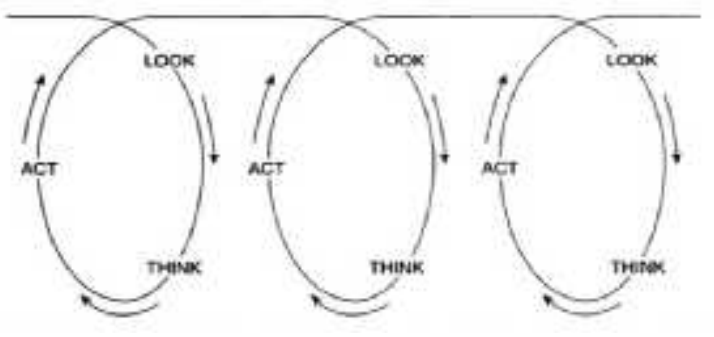

Gambar 3.1.

Model Stringer dalam PTK

Berdasarkan desain penelitian di atas, penelitian dilaksankan selama 2 siklus. Sebelum melaksanakan penelitian, diadakan observasi (look), kemudian peneliti beserta tim kolaborator melakukan refleksi dan memikirkan alternatif pemecahan masalahnya (think), kemudian melakukan tindakan (act) berupa pelakanaan siklus 1 . Setelah dilakukan siklus 1 , kemudian peneliti melihat hasilnya baik pelaksanaan tindakan maupun hasil belajar siswa (look), kemudian memikirkan langkah perbaikan untuk siklus 2 (think), berdasarkan hasil pemikiran, siklus 2 siap dilaksanakan (act).

\section{Subjek dan Setting Penelitian}

Subjek dari penelitian tindakankelas ini adalah siswa kelas 4A SD Negeri Salatiga 06 Kota Salatiga Tahun Pelajaran 2017/2018 yang berjumlah 33, dengan siswa laki-laki sebanyak 11 siswa dan siswa perempuan sebanyak 21 siswa.

\section{Variabel Penelitian}

Variabel dalam penelitian dibedakan menjadi dua, yaitu variabel bebas dan variabel terikat. Variabel bebas (variabel independen) merupakan variabel yang mempengaruhi atau menjadi penyebab terjadinya perubahan pada variabel terikat (variabel dependen) (Sugiyono, 2014: 64). Sedangkan variabel terikat (variabel dependen) merupakan variabel yang dipengaruhi oleh variabel bebas (Sugiyono, 2014: 64). Variabel bebas pada penelitian ini berupa model pembelajaran inquiry berbasis lingkungan Sedangkan variabel terikat pada 
penelitian ini adalah aktivitas dan hasil belajar tematik.

\section{Teknik Pengumpulan Data}

Teknik pengumpulan data pada penelitian ini menggunakan tekni tes dan nontes. Untuk memperoleh data pada variabel bebas berupa pelaksanaan tindakan menggunakan model pembelajaran inquiry berbasis lingkungan digunakan teknik nontes yaitu observasi dan catatan lapangan. Sedangkan untuk memperoleh data hasil belajar tematik menggunakan teknik tes, berupa tes tertulis berbentuk pilihan ganda. Sebelum instrumen yang berupa soal tes tertulis digunakan, harus di uji terlebih dahulu yaitu uji validitas, uji reliabilitas setelah dilakukan uji coba instrumen yang dilaksanakan pada kelas 5. Uji coba dilakukan di kelas 5 karena materi yang diberikan adalah materi yang sudah diajarkan pada anak-anak kelas 5. Uji coba instrumen bertujuan untuk mengetahui soal mana yang sesuai dan dapat digunakan untuk mengukur hasil penelitian. Setelah melakukan uji coba, penghitungannya menggunakan SPSS versi 21. Untuk uji reliabilitas digunakan metode Alpha (Cronbach's). Selain itu, uji instrumen dengan menguji taraf kesukaran. Indikator keberhasilan meliputi Indikator Kinerja dan Indikator Hasil Tindakan.

\section{Teknik Analisis Data}

Teknik analisis data, untuk yang kuantitatif dilakukan seacara deskriptif komparatif yaitu membandingkan hasil belajar berdasarkan nilai tes pada setiap siklusnya. Sedangkan analisis data kualitatif dilakukan dengan cara analisis deskriptif berdasarkan hasil observasi aktivitas kinerja guru dan observasi aktivitas siswa

Teknik analisis data dalam penelitian ini menggunakan deskriptif komparatif, yaitu dengan menghitung persentase ketuntasan hasil belajar siswa pada siklus 1 kemudian dibandingkan dengan persentase ketuntasan hasil belajar siswa pada siklus 2 .

\section{B. HASIL DAN PEMBAHASAN}

Hasil penelitian ini dapat dilihat dengan membandingkan kondisi awal daru hasil studi pendahuluan dengan kondisi setelah dilaksanakan pembelajaran menggunakan model pembelajaran Inquiry. Penelitian ini dilaksanakan dalam dua siklus dengan menerapkan langkah-langkah model pembelajaran Inquiry sesuai sintaknya. Penelitian ini dilakukan dengan tujuan meningkatkan aktivitas dan hasil belajar siswa melalui penerapan model pembelajaran Inquiry berbasis lingkungan. Hasil penelitian terdiri atas aktivitas dan hasil belajar siswa pada siklus 1 dan siklus 2 setelah diberikan tindakan berupa penerapan model pembelajaran Inquiry berbasis lingkungan.

\section{Aktivitas Guru dan Siswa}

Data hasil aktivitas guru dan siswa pada siklus I dan siklus II dilakukan melalui observasi ketika pembelajaran berlangsung. Setelah dilakukan observasi dengan penerapan Inquiry berbasis lingkungan, diperoleh hasil aktivitas pembelajaran tematik sebagai berikut.

Tabel 1. Hasil Observasi Kinerja Guru dan Aktivitas Siswa dalam Penerapan Model Inquiry Berbasis Lingkungan.

\begin{tabular}{lcccc}
\hline \multirow{2}{*}{ Kategori } & \multicolumn{2}{c}{ Siklus I } & \multicolumn{2}{c}{ Siklus II } \\
\cline { 2 - 5 } & $\begin{array}{c}\text { Rata- } \\
\text { rata }\end{array}$ & $\begin{array}{c}\text { Persentase } \\
(\boldsymbol{\%})\end{array}$ & $\begin{array}{c}\text { Rata- } \\
\text { rata }\end{array}$ & $\begin{array}{c}\text { Persentase } \\
(\boldsymbol{\%})\end{array}$ \\
\hline $\begin{array}{l}\text { Aktivitas } \\
\text { Guru }\end{array}$ & 3,2 & 80 & 3,6 & 90 \\
\hline $\begin{array}{l}\text { Aktivitas } \\
\text { Siswa }\end{array}$ & 3,13 & 72,02 & 83,15 & 83,50 \\
\hline
\end{tabular}

Berdasarkan hasil analisis yang diperoleh, maka didapatkan adanya peningkatan aktivitas guru dan siswa dari siklus I ke siklus II. Perolehan hasil aktivitas siswa pada siklus I mencapai $72,02 \%$ dan meningkat menjadi $83,50 \%$ pada siklus II. Begitu pula dengan aktivitas guru mencapai $80 \%$ pada siklus I dan meningkat menjadi 
90\% pada siklus II. Hasil penelitian tersebut menunjukkan bahwa terdapat peningkatan aktivitas guru maupun siswa dari siklus I ke siklus II.

\section{Hasil Belajar Tematik}

Data hasil belajar siswa dengan penerapan model Inquiry terdiri dari data hasil belajar pada siklus I dan siklus II. Hasil belajar tematik siswa pada pembelajaran dengan penerapan model Inquiry berbasis lingkungan dapat dilihat pada tabel 2 .

Tabel 2. Hasil Belajar Tematik Siswa dengan Model Pembelajaran Inquiry Berbasis Lingkungan

\begin{tabular}{ccccc}
\hline \multirow{2}{*}{ Kategori } & \multicolumn{2}{c}{ Siklus I } & \multicolumn{2}{c}{ Siklus II } \\
\cline { 2 - 5 } & $\begin{array}{c}\text { Banyak } \\
\text { Siswa }\end{array}$ & $\begin{array}{c}\text { Persentase } \\
\text { Ketuntasan } \\
(\mathbf{\%})\end{array}$ & $\begin{array}{c}\text { Banyak } \\
\text { Siswa }\end{array}$ & $\begin{array}{c}\text { Persentase } \\
\text { Ketuntasan } \\
(\boldsymbol{\%})\end{array}$ \\
\hline Tuntas & 24 & 73,50 & 30 & 91,00 \\
\hline Tidak Tuntas & 9 & 26,50 & 3 & 9,00 \\
\hline
\end{tabular}

Berdasarkan tabel tersebut, terdapat perbedaan terhadap ketuntasan hasil belajar tematik pada tema Daerah Tempat Tinggalku. Ketuntasan hasil belajar tematik siswa pada siklus I sebesar $73,50 \%$, dan pada siklus II mencapai 91,00\%. Pada siklus 1, banyaknya siswa yang tubtas berjumlah 24 , sedangkan pada siklus 2 , banyaknya siswa yang tuntas berjumlah 30. Hasil tersebut

Tabel 3. Hasil Belajar Tematik Permuatan dengan Model Pembelajaran Inquiry Berbasis Lingkungan

\begin{tabular}{|c|c|c|c|c|c|c|c|c|}
\hline & \multicolumn{4}{|c|}{ Siklus I } & \multicolumn{3}{c|}{ Siklus II } \\
\hline \multirow{2}{*}{ Kategori } & \multicolumn{2}{|c|}{$\begin{array}{c}\text { Bahasa } \\
\text { Indonesia }\end{array}$} & \multicolumn{2}{|c|}{ IPA } & \multicolumn{1}{c|}{$\begin{array}{c}\text { Bahasa } \\
\text { Indonesia }\end{array}$} & \multicolumn{2}{c|}{ IPA } \\
\cline { 2 - 9 } & $F$ & $\%$ & $f$ & $\%$ & $f$ & $\%$ & $f$ & $\%$ \\
\hline Tuntas & 21 & $63,63 \%$ & 22 & $66,60 \%$ & 25 & $79,41 \%$ & 28 & $84,84 \%$ \\
\hline Tidak Tuntas & 12 & $39,39 \%$ & 11 & $33.30 \%$ & 7 & $20,59 \%$ & 4 & $12,12 \%$ \\
\hline Mising & 0 & & 0 & & 1 & & 1 & \\
\hline
\end{tabular}

Hasil pembelajaran pada siklus II lebih besar dibandingkan pada siklus I. Pada muatan Bahasa Indonesia di siklus I ketuntasan hasil belajar menunjukkan hasil dari 33 siswa terdapat 21 siswa $(63,63 \%)$ mencapai kategori tuntas dan 12 siswa $(39,39 \%)$ dengan kategori tidak tuntas. Sedangkan pada siklus II menunjukkan hasil dari 33 siswa terdapat 25 siswa $(79,41 \%)$ mencapai kategori tuntas dan 7 siswa $(20,59)$ dengan kategori tidak tuntas. Selanjutnya hasil belajar siklus I pada muatan pelajaran IPA menunjukkan dari 33 siswa terdapat 22 siswa $(66,60 \%)$ mencapai kategori tuntas dan 11 menyatakan bahwa ketuntasan belajar tematik pada siklus II lebih besar dibandingkan pada siklus I. Hasil belajar tematik tersebut dapat dijabarkan permuatan pelajaran IPA dan Bahasa Indonesia. Hasil belajar pada siklus I dan siklus II permuatan pelajaran secara rinci dapat dilihat pada tabel 3.

siswa $(33,30 \%)$ dengan kategori tidak tuntas. Sedangkan pada siklus II menunjukkan dari 33 siswa terdapat 28 siswa $(84,84 \%)$ mencapai kategori tuntas dan 4 anak $(12,12 \%)$ dengan kategori tidak tuntas. Berdasarkan hasil belajar yang diperoleh, maka dapat disimpulkan bahwa penerapan Inquiry berbasis lingkungan dapat meningkatkan aktivitas dan hasil belajar siswa

\section{PEMBAHASAN}

Jenis data yang digunakan pada PTK ini adalah jenis data kuantitatif dan kualitatif. Sumber data yang digunakan pada penelitian 
ini antara lain adalah guru, siswa, data dokumen, dan catatan lapangan. Adapun Instrumen penelitian yang digunakan adalah observasi, tes, dan dokumentasi.

Siklus 1 dilaksanakan selama dua pertemuan yaitu pada tanggal 22 dan 23 Maret 2018. Pada pertemuan pertama dilakukan kegiatan pembelajaran selama 6 jam pembelajaran. Pertemuan kedua digunakan untuk kegiatan evaluasi. Pembelajaran dilaksanakan berdasarkan langkah-langkah pembelajaran yang telah dirancang dalam Rencana Pelaksanaan Pembelajaran (RPP) meskipun masih terdapat tahap atau langkah yang tidak terlaksana.

Berdasarkan data hasil belajar dan observasi tindakan pada siklus 1, kemudian diadakan refleksi bersama tim kolaborator. Kekurangan pada siklus 1 kemudian diperbaiki pada siklus 2. Siklus 2 dilaksanakan selama 6 jam pelajaran pada dua pertemuan, yaitu tanggal 5 dan 6 April 2018.

Siklus 2 dilaksanakan selama dua pertemuan yaitu pada tanggal 5 dan 6 April 2018. Pada pertemuan pertama dilakukan kegiatan pembelajaran selama 6 jam pembelajaran. Pertemuan kedua digunakan untuk kegiatan evaluasi. Pembelajaran dilaksanakan berdasarkan langkah-langkah pembelajaran yang telah dirancang dalam Rencana Pelaksanaan Pembelajaran (RPP).

Berdasarkan hasil tes formatif pada siklus 2, ketuntasan hasil belajar tematik meningkat menjadi $91 \%$ dan sudah memenuhi indikator keberhasilan. Hal ini diduga karena proses pembelajaran dengan model inquiry sudah dilaksanakan dengan lebih baik, semua sintak model Inquiry telah dilakukan dengan baik. Selain berdampak pada peningkatan hasil belajar, pembelajaran menggunakan model tersebut memberikan beberapa dampak pengiring, diantaranya: (1) siswa bersemangat dalam mengikuti pembelajaran; (2)kemampuan berpikir kritis lebih berkembang, kemampuan berkolaborasi, dan kemampuan berkomunkasi siswa terbangun dengan adanya percobaan dan kerja kelompok yang mereka lakukan; (3) meningkatnya kemampuan berpendapat, siswa berhak mengemukakan pendapatnya melalui hipotesis yang mereka ajukan; menumbuhkan sikap ilmiah; serta (5) pembelajaran lebih bermakna karena siswa membangun dan membuktikan sendiri dalam membangun suatu konsep baru melalui lingkungan sekitar mereka.

Penerapan model pembelajaran Inquiry berbasis lingkungan dalam pembelajaran tematik menambah pengetahuan masyarakat terhadap perkembangan ilmu pendidikan, terutama pada pembelajaran tematik di jenjang sekolah dasar yang sesuai dengan tuntutan kurikulum 2013. Pada pembelajaran tematik dengan menggunakan model pembelajaran Inquiry berbasis lingkungan ini sudah mencakup lima unsur pendekatan saintifik yang meliputi mengamati, menanya, mengumpulkan informasi, mengolah informasi, dan mengkomunikasikan. Hal ini sesuai dengan pendapat Sani (2014) bahwa pendekatan saintifik pada umumnya melibatkan kegiatan pengamatan atau observasi yang dibutuhkan untuk perumusan hipotesis atau mengumpulkan data. Hal tersebut dapat ditemukan dalam pembelajaran menggunakan model Inquiry, dimana dalam sintaknya sudah terdapat kegiatan ilmiah seperti merumuskan hipotesis, mengumpulkan data, menguji hipotesis, sampai merumuskan kesimpulan.

Pembelajaran menggunakan model Inquiry, juga tentunya dapat mengembangkan kemmapuan berpikir siswa dengan cara merumuskan masalah, merumuskan hhipotesis, mengumpulkan data, menguji hipotesis, hingga menyimpulkan semua itu menuntut siswa untuk berpikir kritis. Hal ini sependapat dengan Hosnan (2014: 341) yang menyatakan bahwa pembelajaran Inquiry 
merupakan rangkaian kegiatan pembelajaran yang menekankan pada proses berpikir kritis dan analitis untuk mencari dan menemukan sendiri jawaban dari suatu masalah yang telah dirumuskan. Selain itu, yang tak kalah penting adalah pembelajaran menggunakan model Inquiry juga memenuhi kriteria HOTS (High Thinking Order Skills). Agar pembelajaran yang HOTS (High Thinking Order Skills) dapat terwujud maka guru perlu merancang suatu pembelajaran yang sesuai dengan kompetensi dasar yang ingin

Pembelajaran juga bersifat menemukan dan membangun pengetahuannya sendiri, sehingga pengetahuan tersebut tidak mudah dilupakan oleh siswa. Hal ini berdampak pada daya ingat siswa tentang suatu konsep baru. Siswa tidak mudah lupa dengan konsep atau pengetahuan baru yang diperolehnya. Ingatan tentang konsep baru yang tidak mudah hilang itu akan berdampak pada proses perolehan pengetahuan selanjutnya, dimana dalam mendapatkan pengetahuan baru siswa perlu mengaitkan antara konsep yang telah dimiliki sebelumnya dengan konsep yang akan diperolehnya.

Oleh karena itu, peneliti menerapakan model Inquiry berbasis lingkungan agar hasil belajar meningkat. Selain itu, pembelajaran juga bermakna bagi siswa karena materi yang dibangun berdasarkan pengalaman belajarnya sendiri dapat menjadi bagian penting yang akan selalu diingat oleh siswa.

Model pembelajaran inquiry berbasis lingkungan dinyatakan dapat meningkatkan hasil belajar tematik apabila ketuntasan siswa pada siklus 2 lebih besar dibanding dengan ketuntasan peserta didi pada siklus 1 . Penelitian ini dapat dinyatakan berhasil apabila terjadi peningkatan dari hasil belajar matematika pada siklus 2. Selain itu ketuntasan hasil belajar mencapai $75 \%$.

\section{SIMPULAN}

Berdasarkan hasil yang diperoleh selama pemberian tindakan, penerapan model
Inquiry berbasis liingkungan dapat meningkatkan aktivitas dan hasil belajar tematik siswa. Hal ini ditunjukkan pada ketuntasan hasil belajar siswa siklus I dengan muatan Bahasa Indonesia sebesar 63,63\% dengan 21 siswa tuntas dan mengalami peningkatan pada siklus II menjadi $79,41 \%$ dengan 25 siswa tuntas. Muatan IPA pada siklus I menunjukkan bahwa ketuntasan mencapai $66,60 \%$ dengan 22 siswa tuntas. Sedangkan pada siklus II, muatan IPA mengalami peningkatan menjasi $84,84 \%$ dengan 28 siswa tuntas. Peningkatan hasil belajar terjadi karena adanya peningkatan aktivitas guru dan siswa selama proses pembelajaran. Selain hasil belajar tematik meningkat, pembelajaraan juga memberikan dampak positif bagi siswa, antara lain siswa bersemangat dalam melaksanakan serangkain kegiatan selama pembelajaran berlangsung, kemampuan berbikir siswa juga meningkat melalui percobaan yang dikerjakan secara berkelompok, dan pembelajaran lebih bermakna bagi siswa maupun guru.

Berdasarkan simpulan di atas dan kondisi selama penelitian, peneliti dapat memberi saran bagi guru bahwa model Inquiry merupakan salah satu model yang dipilih pemerintah dalam menerapkan kurikulum 2013. Model Inquiry berbasis lingkungan dapat dikembangkan pada tema dan jenjang kelas lain dengan disesuaikan pada kompetensi dasar. Pemanfaatan lingkungan sebagai sumber belajar sangat mempengaruhi kemudahan siswa dalam memahami sebuah materi. Sehingga, penyusunan rencana pembelajaran bisa disesuaikan dengan materi dan lingkungan sekitar.

DAFTAR PUSTAKA

Anderson, D.W., Vault, V.D. \& Dickson, C.E. 1999. Problems and Prospects for the Decades Ahead: Competency Based Teacher Education. Berkeley: McCutchan Publishing Co. 
Saukah, A. \& Waseso, M.G. (Eds.). 2002. Menulis Artikel untuk Jurnal Ilmiah (Edisi ke-4, cetakan ke-1). Malang: UM Press.

Russel, T. 1998. An Alternative Conception: Representing Representation. Dalam P.J. Black \& A. Lucas (Eds.), Children's Informal Ideas in Science (hlm. 62-84). London: Routledge.

Kansil, C.L. 2002. Orientasi Baru Penyelenggaraan Pendidikan Program Profesional dalam Memenuhi Kebutuhan Dunia Industri. Transpor, XX (4):57-61.

Pitunov, B. 13 Desember, 2002. Sekolah Unggulan ataukah Sekolah Pengunggulan? Majapahit Pos, hlm. 4 \& 11 .

Jawa Pos. 22 April, 1995. Wanita Kelas Bawah Lebih Mandiri, hlm. 3.

Pusat Pembinaan dan Pengembangan Bahasa. 1978. Pedoman Penulisan Laporan Penelitian. Jakarta: Depdikbud.

Undang-undang Republik Indonesia Nomor 20 Tahun 2003 tentang Sistem Pendidikan Nasional. 2004. Malang: Angkasa.

Ary, D., Jacobs, L.C. \& Razavieh, A. 1976. Pengantar Penelitian Pendidikan.
Terjemahan oleh Arief Furchan. 1982. Surabaya: Usaha Nasional.

Makmara. Thontjie. 2009. Tuturan Persuasif Wiraniaga dalam Berbahasa Indonesia: Kajian Etnografi Komunikasi. Disertasi tidak diterbitkan. Malang: Pascasarjana Universitas Negeri Malang.

Waseso, M.G. 2001. Isi dan Format Jurnal Ilmiah. Makalah disajikan dalam Seminar Lokakarya Penulisan Artikel dan Pengelolaan Jurnal 1lmiah, Universitas Lambungmangkurat, Banjarmasin, 9-11 Agustus.

Hitchcock, S., Carr:, L. \& Hall, W. 1996. A Survey of STM Online Journals, 1990-1995: The Calm before the Storm, (Online), (http://journal.ecs.soton.ac.uk/survey/s urvey.html, diakses 12 Juni 1996).

Widiati, Utami. 2008. PembelajaranMembaca-Menulis melalui Buddy Journals untuk Meningkatkan Kemampuan Menulis Mahasiswa Jurusan Sastra Inggris. Jurnal Bahasa dan Seni. (Online), Tahun 36, Nomor 2, Agustus 2008 (http://sastra.um.ac.id, diakses 3 Februari 2010). 